\title{
Sustainable Oil-Palm Cultivation: We Need to Use 'Gene Technology' to Boost Palm-Oil Production
}

\section{Subhash J Bhore*}

Department of Biotechnology, Faculty of Applied Sciences, AIMST University, Bedong-Semeling Road, Bedong, 08100, Kedah, Malaysia

Vegetable oil and fats are very essential in our daily life. There are several oil-producing crops, but mainly 8 crops (oil-palm, soybean, canola, sunflower, peanut, cotton, coconut and olive) contributes in the world market of the vegetable oil and fats [1]. Out of these 8 oil-producing crops, oil-palm [Elaeis guineensis Jacq (Tenera)] is the number one in the sense of its total yield per unit area (5 tonnes/hectare/ year) of cultivation and total supply in the world market of vegetable oil and fats. There are three fruit forms in E. guineensis, namely, 'Dura' (thick-shelled), 'Pisifera' (shell-less) and 'Tenera' (thin-shelled) [2,3]. Tenera form is a hybrid between Dura $(+)$ and Pisifera $(\hat{O})$. This $E$. guineensis Tenera is cultivated commercially in several countries due to its high oil yielding trait; but, Indonesia and Malaysia are the major producers and exporters of the palm-oil [1]. As of August 22, 2013, the world human population was 7.173 billion, and the demand for the vegetable oil and fats is steadily increasing. Currently, the market share of the palm-oil in the world market of vegetable oil and fats is about $34 \%$ [1]. Oil-palm does have a great potential to meet increasing demand of vegetable oil and fats [4,5]. In addition, palm-oil is also considered as a suitable raw material for biodiesel production [6,7]. Oil-palm cultivation is a good profitable business; hence, small, medium and large plantation companies are enthusiastically investing in the oil-palm plantations. Therefore, oil-palm plantation are rapidly expanding in the oil-palm growing countries. Yes, we do need to cultivate oil-palm for the production of palm-oil to meet the continuously growing demand for vegetable oil and fats. But, a growing body of research is clearly indicating that palm-oil farming can cause damaging deforestation and reduce biodiversity [8]. A huge amount of forest land is being converted into oil-palm plantations in the oil-palm growing countries, and it's alarming. We cannot afford deforestation forever to make forest land available to expand oil-palm plantations.

Forests are considered as nature's pharmacy, and it is strongly believed that there may be millions of undiscovered species of plants, insects and microorganisms in it, and numerous species could be indigenous. However, in the process of deforestation, we might be losing number of rare and valuable species forever [8-10]. Even if, forest fragmentation technique is used, we are bound to lose valuable species [11]. From the socio-economic and political point of view, oil-palm cultivation and palm-oil business is offering a vital income to smallscale farmers, locals, and as a whole to the respective oil-palm growing countries; but, environmental impact of deforestation is raising several conservation concerns $[8,12-15]$. We should not ignore these concerns and need to find out innovative ways of conserving forests.

In fact, all countries do have a decisive right to cultivate the crops suited to their geographical and environmental conditions. We all also know that the preservation of forests is essential for the survival of human race on this planet; but, we are continuously clearing our forests. The international community needs to find an effective strategy to protect our forests before it becomes very late. However, we cannot just demand to stop deforestation without understanding the real issues. One need to understand that palm-oil based business is very important for the economy of the oil-palm growing countries.

It can be argued that if the international community expects that oil-palm growing countries should stop deforestation (for oilpalm cultivation) then (naturally) these countries should get some compensation from international community to preserve forests for the benefit of the human race.

For the preservation of valuable forests in the oil-palm growing countries and to have a sustainable supply of palm-oil for the world community, an efficient and effective cross-talk amongst global forest experts, climatologist, ecologists, innovators, genetic engineers (scientists), policy makers, and other relevant stakeholders is essential to develop the innovative strategy.

By realizing the importance of forest preservation, oil-palm industry is working towards sustainable oil-palm farming practices. In this line, systematic extensive research on oil-palm is essential to explore various ways of developing a sustainable strategy for its cultivation. A prudent and an efficient use of 'gene technology' (also called 'genetic engineering' or 'genetic modification' or 'GM technology') is one of the options available to modify oil-palm to boost palm-oil production. This can help in developing sustainable oil-palm farming.

The advances in the field of 'gene technology' have revolutionized the crop biotechnology along with the other sectors of biotechnology. The 'gene technology' can be used to genetically modify food crop plants for the desired improvements and or for the sustainable food supply [16-19]. By using 'gene technology', if we modify oil-palm to enhance its oil yield then it could be useful to meets the growing demand for palm-oil in a sustainable manner.

Most recently, Malaysian Palm Oil Board (MPOB) and their collaborators from USA has published the oil-palm [the African oilpalm, E. guineensis, and the South American oil-palm, E. oleifera] genome [20]. Interestingly, the same research group has also reported the discovery of oil yield and the shell-less phenotype controlling 'SHELL' gene in oil-palm [3]. This advancement in oil-palm research is bound to have a huge impact in the oil-palm industry in the near future. By using 'gene technology', this 'SHELL' gene can be exploited to increase the palm-oil content in oil-palm fruits. If we succeed then it will be a significant contribution in achieving the goal of sustainability in oil-palm cultivation.

In brief, to meet the challenges of big demand for vegetable oil and fats, palm-oil production should be increased; but, the importance of forest preservation should not be ignored. By utilizing genetic information derived from oil-palm genome, a possibility of developing a high oil yielding oil-palm (super-oil-palm) needs to be explored. A prudent use of 'gene technology' has a potential to make it possible.

*Corresponding author: Subhash J Bhore, Department of Biotechnology, Faculty of Applied Sciences, AIMST University, Bedong-Semeling Road, Bedong, 08100, Kedah, Malaysia, E-mail: subhashbhore@gmail.com, subhash@aimst.edu.my

Received September 04, 2013; Accepted September 06, 2013; Published September 12, 2013

Citation: Bhore SJ (2013) Sustainable Oil-Palm Cultivation: We Need to Use 'Gene Technology' to Boost Palm-Oil Production. Gene Technology 2: e105. doi: 10.4172/2329-6682.1000e105

Copyright: ( 2013 Bhore SJ. This is an open-access article distributed under the terms of the Creative Commons Attribution License, which permits unrestricted use, distribution, and reproduction in any medium, provided the original author and source are credited. 
Citation: Bhore SJ (2013) Sustainable Oil-Palm Cultivation: We Need to Use 'Gene Technology' to Boost Palm-Oil Production. Gene Technology 2: e105. doi: 10.4172/2329-6682.1000e105

Page 2 of 2

\section{References}

1. USDA (2013) United States Department of Agriculture. Retrived 2013-08-23.

2. Muniran F, Bhore SJ, Shah FH (2008) Micropropagation of Elaeis guineensis Jacq. 'Dura': Comparison of three basal media for efficient regeneration. Indian J Exp Biol 46: 79-82.

3. Singh R, Low ET, Ooi LC, Ong-Abdullah M, Ting NC, et al. (2013) The oil palm SHELL gene controls oil yield and encodes a homologue of SEEDSTICK. Nature 500: 340-344.

4. Ong AS, Goh SH (2002) Palm oil: a healthful and cost-effective dietary component. Food Nutr Bull 23: 11-22.

5. Fry J, Fitton C (2010) The importance of the global oils and fats supply and the role that palm oil plays in meeting the demand for oils and fats worldwide. J Am Coll Nutr 29: 245S-252S.

6. Mueller D, Ferrão MF, Marder L, da Costa AB, Schneider Rde C (2013) Fourier transform infrared spectroscopy (FTIR) and multivariate analysis for identification of different vegetable oils used in biodiesel production. Sensors (Basel) 13: 4258-4271.

7. Da Rós PC, Freitas L, Perez VH, de Castro HF (2013) Enzymatic synthesis of biodiesel from palm oil assisted by microwave irradiation. Bioprocess Biosyst Eng 36: 443-451.

8. Gilbert N (2012) Palm-oil boom raises conservation concerns. Nature 487: 14 15.

9. Koh LP, Wilcove DS (2007) Cashing in palm oil for conservation. Nature 448: 993-994.
10. Tollefson J (2013) Forest ecology: Splinters of the Amazon. Nature 496: 286289

11. Ferraz G, Russell GJ, Stouffer PC, Bierregaard RO Jr, Pimm SL, et al. (2003) Rates of species loss from Amazonian forest fragments. Proc Natl Acad Sci U S A 100: 14069-14073.

12. Moore S, Evans CD, Page SE, Garnett MH, Jones TG, et al. (2013) Deep instability of deforested tropical peatlands revealed by fluvial organic carbon fluxes. Nature 493: 660-663.

13. Gibson L, Lee TM, Koh LP, Brook BW, Gardner TA, et al. (2011) Primary forests are irreplaceable for sustaining tropical biodiversity. Nature 478: 378-381.

14. Venter O, Meijaard E, Wilson K (2008) Strategies and alliances needed to protect forest from palm-oil industry. Nature 451: 16.

15. Goodall J, Pintea L (2010) Securing a future for chimpanzees. Nature 466 180-181.

16. Bhore SJ (2008) GM technologies. Current Science 95: 1391-1393.

17. Prakash CS (2013) GM in the media: A look at the news from around the world on genetically modified food and crops. GM Crops Food 4: 85-87.

18. Elsanhoty RM, Al-Turki Al, Ramadan MF (2013) Prevalence of Genetically Modified Rice, Maize, and Soy in Saudi Food Products. Appl Biochem Biotechnol .

19. Heap B (2013) Europe should rethink its stance on GM crops. Nature 498: 409.

20. Singh R, Ong-Abdullah M, Low ET, Manaf MA, Rosli R, et al. (2013) Oil palm genome sequence reveals divergence of interfertile species in Old and New worlds. Nature 500: 335-339. 